\title{
Correction to: Patellar fixation graft via suture anchors versus tunnel techniques during isolated MPFL reconstruction for recurrent patellofemoral instability: a systematic review of the literature
}

\author{
Filippo Migliorini ${ }^{1} \cdot$ Arne Driessen $^{1} \cdot$ Valentin Quack $^{1} \cdot$ Hanno Schenker $^{1} \cdot$ Markus Tingart $^{1} \cdot$ Jörg Eschweiler $^{1}$
}

Published online: 22 June 2021

(c) The Author(s) 2021

\section{Correction to: \\ Archives of Orthopaedic and Trauma Surgery (2020) 140:1201-1210 \\ https://doi.org/10.1007/s00402-020-03420-8}

The article Patellar fixation graft via suture anchors versus tunnel techniques during isolated MPFL reconstruction for recurrent patellofemoral instability: a systematic review of the literature, written by Filippo Migliorini, Arne Driessen, Valentin Quack, Hanno Schenker, Markus Tingart and Jörg Eschweiler, was originally published Online First without Open Access. After publication in volume 140, issue 9, page 1201-1210 the author decided to opt for Open Choice and to make the article an Open Access publication. Therefore, the copyright of the article has been changed to $($ ) The Author(s) 2021 and this article is licensed under a Creative Commons Attribution 4.0 International License, which permits use, sharing, adaptation, distribution and reproduction in any medium or format, as long as you give appropriate credit to the original author(s) and the source, provide a link to the Creative Commons licence, and indicate if changes were made. The images or other third party material in this article are included in the article's Creative Commons licence, unless indicated otherwise in a credit line to the material. If material is not included in the article's Creative Commons licence and your intended use is not permitted by statutory regulation or exceeds the permitted use, you will need to obtain permission directly from the copyright holder. To view a copy of this licence, visit http://creativecommons. org/licenses/by/4.0/.

The original article has been corrected.

Funding Open Access funding enabled and organized by Projekt DEAL.

Open Access This article is licensed under a Creative Commons Attribution 4.0 International License, which permits use, sharing, adaptation, distribution and reproduction in any medium or format, as long as you give appropriate credit to the original author(s) and the source, provide a link to the Creative Commons licence, and indicate if changes were made. The images or other third party material in this article are included in the article's Creative Commons licence, unless indicated otherwise in a credit line to the material. If material is not included in the article's Creative Commons licence and your intended use is not permitted by statutory regulation or exceeds the permitted use, you will need to obtain permission directly from the copyright holder. To view a copy of this licence, visit http://creativecommons.org/licenses/by/4.0/.

The original article can be found online at https://doi.org/10.1007/ s00402-020-03420-8.

Filippo Migliorini

Migliorini.mg@gmail.com

1 Department of Orthopaedics, RWTH Aachen University

Clinic, Pauwelsstraße 30, 52074 Aachen, Germany 
Publisher's Note Springer Nature remains neutral with regard to jurisdictional claims in published maps and institutional affiliations. 